\title{
Comparison of the mechanical properties of meat and fish salamis
}

\section{Et ve balık salamlarının mekanik özelliklerinin karşılaştırılması}

\author{
M. Tolga Dinçer* (D) • Ö. Alper Erdem • E. Burcu Şen Yılmaz
}

Department of Fishery and Processing Technology, Faculty of Fisheries, Ege University, İmir, Turkey

${ }^{*}$ Corresponding author: tolga.dincer@ege.edu.tr

How to cite this paper:

Dinçer, M.T., Erdem, Ö.A. \& Şen Yılmaz, E. (2017). Comparison of the mechanical properties of meat and fish salamis. Ege Journal of Fisheries and Aquatic Sciences, 34(4):443-449. doi: 10.12714/egejfas.2017.34.4.11

\begin{abstract}
The aim of this study was to determine the textural and sensory properties of prepared fish salami from saithe (Polachius virens) fillets. In the research the mechanical property of produced fish salami was compared to purchased beef salami. The comparison was realized in their textural, physical, and sensorial properties. Acceptable textural desirability was observed with the formulation, which was improved with the addition of selected spices. Prepared fish salami exhibited a weaker texture than purchased beef salami according to mechanical properties (TPA and shear test), but no difference ( $P>0.05$ ) in overall liking was determined by the panelists.
\end{abstract}

Keywords: Fish salami, water holding capacity, shear test, cooking loss, color values

Öz: Çalışmanın amacı mezgit (Polachius virens) filetolarından hazırlanmış olan balık salamının dokusal ve duyusal özaelliklerinin tespit edilmesidir. Çalışmada üretilen balık salamının ve piyasada bulunan et salamının mekanik özelliklerinin kıyaslaması yapılmıştır. Kıyaslama ürünlerin dokusal, fiziksel ve duyusal özellikleri arasında gerçekleştirimiştir. Kullanılan formül ve baharat çeşitleri sayesinde kabul gören bir doku elde edilmiştir. Üretilen balık salamının dokusal yapısı, piyasadan satın alınan et salamı ile kıyaslanınca, mekanik özellikler açısından (TPA ve kesit testi) daha yumuşak olmuş fakat panelistler tarafından genel beğeni açısından bir fark görülmemiştir $(P>0.05)$.

Anahtar kelimeler: Balık salamı, su tutma kapasitesi, kesit testi, pişirme kaybı, renk değerleri

\section{INTRODUCTION}

Fish mince offers great flexibilities in production, formulation, and also texture modification (Yoon et al., 1991) in emulsified products. Many fish based products can be produced by using fish mince such as; sticks, cakes, sausages, salamis, and patties. But seafood is known as more perishable than other high-protein foods. Cool chain should not be broken, and protecting case and package should be used for preserving quality. The production in fish based emulsion products can be alternatives for the usual high-fat, high-calorie pork, or beef salami and sausages. Fish is known as a rich source of longchain $\mathrm{n}-3$ fatty acids, and those fatty acids are known to have a range of health benefits. Especially potential roles in reducing the risk of coronary heart disease, inflammatory disorders, and immune disorders have resulted in interest among consumers and manufacturers (DeDeckere et al., 1998; Trautwein, 2001). Besides, emulsified fish products like salami and sausage can be other alternatives for food manufacturers. Mince of fish and surimi/surimi powder have been used as a raw material for emulsion sausage production for many years, especially in the Asian countries (Konno, 2005). All over the world the health organisations recommend limiting the intake of saturated fatty acids and cholesterol (Kris-Etherton et al., 1988). The best solution might be to encourage consumers to consume fishbased products.

Emulsion sausages and salamis are widely consumed in both Western and Asian countries (Panpipat and Yonsawatdigul, 2008). Fish salami production steps were just like the products made from beef, pork, and chicken salamis which had nearly $20-30 \%$ fat in formulas. Distinctions in the steps were using higher contents of fish flesh, lower amounts of fat, and different types of seasoning. Texture is the most important sensory property for acceptability of this kind of seafood product (Botta, 1991). The overall quality of seafood is generally based on the sensorial acceptability by the consumer (Sikorski et al., 1991). Wholesomeness is affected by chemical composition and microbiological considerations, while sensory acceptability is determined largely by flavor and texture (Sawyer et al., 1984). Destabilization of fat and water during cooking causes an undesirable separation of fat and water which results in poor texture (Lee et al., 1987). Soybean proteins have the ability to enhance and stabilize fat emulsions 
and improve viscosity, texture and moisture retention as well as overall yields in emulsified products (Kinsella 1979). So the principles of true emulsions have been employed to explain the mechanism by which fat is stabilized. There are various studies about the meat emulsions (Gerigk et al., 1986; Perchonok and Regenstein 1986). However, there are few studies on fishbased emulsion products (Cardoso et al., 2008; Moreira et al., 2002; Panpipat and Ravishankar 1992; Panpipat and Yonsawatdigul 2008). Therefore, the objective of this study was to show how fish salami is produced and to investigate and compare its mechanical properties and color with commercial beef salami.

\section{MATERIALS AND METHODS}

\section{Raw material}

As raw material, frozen and skinless saithe (Polachius virens) fillets were preffered in the current study. Fish samples were supplied by a commercial seafood company. And the used beef salamis were purchased from a commercial market chain. It was known that frozen fish fillet samples were stored for 2 months at $-24{ }^{\circ} \mathrm{C}$. At the beginning of production fish samples were thawed $(10 \mathrm{kgs})$ in to $-2^{\circ} \mathrm{C}$. Other ingredients (Sunflower oil, fat, spices) were purchased from the suppliers. Same Turkish Standard Institute (TSI, standard number 9269/ December 1991) formula was used for fish salami production. Fish mince was replaced with beef mince and modification of spices were the difference in the formula.

\section{Formulation}

The formula and ingredients of the fish salami was as follows: skinless saithe fillets, 67.29 ; ice, 16.15; beef fat, 5.04; sun flower oil, 5.05 ; soy protein concentrate, 2.36; potato starch (modified), 2.36; salt, 1.01; sodium tripolyphosphate (STPP), 0.17 ; red pepper, 0.07; black pepper, 0.13; sugar, 0.13; pimento, 0.07; coriander, 0.07; ginger, 0.03; ascorbic acid, 0.02 ; sodium nitrite, $0.01 \mathrm{~g}$.

\section{Preparation of Salami}

Frozen fish fillets were thawed overnight in the fridge $\left(0,+4^{\circ} \mathrm{C}\right)$. Fish filets were chopped with using $2 \mathrm{~cm}$ grinding blades in kitchen aid grinder $(2 \mathrm{~kg} / \mathrm{min}$, model KPM 5 , St. Joseph, MI, USA) equipped with a $6 \mathrm{~mm}$ diameter circular perforated metallic screen and pusher. At the same time, beef fat was minced, and appropriate rations were prepared $(750 \mathrm{~g})$. Appropriate quantities of various additives were weighed to produce $15 \mathrm{~kg}$ of dough.

Salami dough was prepared in sequential stages as follows: First, the shredded filet is mixed with an industrial bowl cutter for 2 minutes with salt and STPP (20-kg capacity; Mainca Bowl Cutter model C-14, Berkshire, UK). During the mixing process, the internal temperature of the dough was recorded as $-2.16 \pm 0.09^{\circ} \mathrm{C}$. In the second stage, ice water ( $1 / 3$ of the total), soy protein concentrate, and potato starch were added for 1 minute with additional mixing. After that, fat and sunflower oi were added separately and each was mixed for 1 minute.
Spices and a 1/3 ice water were added. The final step included the addition of additives and preservatives and the rest of the iced water. Additional stirring was carried out at the same rate for 2 minutes. Then stuffed in a casing which has a length of 15 $\mathrm{cm}$ and a radius of $2.5 \mathrm{~cm}$ and a weight of about $250 \mathrm{~g}$. The stuffed dough was dried in a $80^{\circ} \mathrm{C}$ conventional oven (model FKG-042, Inoksan Industrial Equipments, Bursa, Turkey) for 35 minutes.

After drying, the salamis were immediately cooled in ice water $(1: 1, v / v)$. After being sealed with a stapler, the salamis were hung on, rinsed quickly with cold water, and dough residues were removed.

The salamis were then cooked for 3 hours at $90^{\circ} \mathrm{C}$ scalding boiler (Model BKR-054, Inoksan Industrial Equipment, Bursa, Turkey) with an internal temperature of $75^{\circ} \mathrm{C}$ (measured with a thermocouple probe). The cooled salamis were kept overnight in a refrigerator $\left(0+4^{\circ} \mathrm{C}\right)$ and used the following day.

\section{Color measurement}

The color measurement was carried out using the Schubring (2002) method, measuring 10 times using different parts of the upper smooth surface. In the CIE Laboratory system, $L$ * indicates the intensity of light in black from 0 to 100 scales; $a{ }^{*}(+)$ red or $(-)$ green, and $b{ }^{*}(+)$ indicates yellow or (-) blue.

\section{Texture profile analysis (TPA)}

Texture Profile Analysis (TPA) was performed using the TA-XT Plus texture analyzer (Stable Micro Systems, Godalming, UK) according to Schubring (2003) method. Prior to the test, the salami samples were equilibrated to room temperature for 30 minutes and sectioned into a $2 \mathrm{~cm}$ thick layer drawn into a $5 \mathrm{~cm}$ diameter cylinder. The samples were compressed twice in a cross speed of $0.80 \mathrm{~mm} / \mathrm{sec}$ to $65 \%$ of the original height using a $5 \mathrm{~cm}$ diameter cylindrical probe. The mechanical properties of hardness, cohesiveness, springiness, resilience and chewiness were determined by the resulting force/deformation curves.

\section{Shear test}

Sample loading, test conditions, and sample preparation followed the procedure described by Su et al. (2000). The samples were compressed to $60 \%$ of their original height at a cross speed of $0.80 \mathrm{~mm} / \mathrm{sec}$ using a Warner-Bratzler blade (Stable Micro Systems, Godalming, Surrey, UK) once set up with a $25 \mathrm{~kg}$ load cell. Shear force and cutting samples were detected with a Warner-Bratzler knife attached to the same texture analyzer. The maximum force (shear force) to cut the sample and the work required to move the blade along the sample (work of shearing) were recorded.

\section{Kramer test}

The firmness of the sample was measured using a texture analyzer equipped with a Kramer shear-compression test cell with 5 blade aluminum plates. $40.000 \mathrm{~mm} / \mathrm{sec}$ cross head 
speed was used in the test. Samples were cut in $25 \times 50 \times 12$ $\mathrm{mm}$ sizes and placed in the cells; five samples were used. Peak values were recorded during drilling of samples (Kao and Lin, 2006).

\section{Pate penetration}

The minced sample was placed on an 8-hole plate. The samples are compressed once using a multi-needle probe at a crosshead distance of $15,000 \mathrm{~mm} / \mathrm{sec}$. The test speed was set at $1.10 \mathrm{~mm} / \mathrm{sec}$ and peak values were recorded during drilling of samples while in operation (Smewing, 1996).

\section{Water-holding capacity (WHC)}

Expressible moisture of salami samples was measured with WHC using a filter paper pressing method as described by Schubring et al. (2003) with slight modification. Salami pieces (21 $\mathrm{mm}$ in diameter, $20 \mathrm{~mm}$ thick), were placed between parallel plates with a pair of filter paper (Schleicher \& Schuell $2043 \mathrm{~A}, 7 \mathrm{~cm} \times 7 \mathrm{~cm}$ ) using a texture analyzer TA-XT Plus (Stable Micro Systems), Godalming, Surrey, UK. A $25 \mathrm{~kg}$ load cell and a cross head speed of 1.7 bar / s were used for pressing the samples.

The samples were compressed to $90 \%$ deformation and held for 10 seconds. Percentage expressible moisture was used as the WHC and was calculated as: $100 \times$ (initial weight final weight)/initial weight.

\section{Cooking loss}

Cooking loss was calculated from differences in the weight of uncooked and cooked samples and expressed as a percentage of the initial weight.

The method used during the test is described in weight (Boles and Swan 1996). The samples were placed in polyethylene bags and cooked in a water bath at $100^{\circ} \mathrm{C}$ until an internal temperature of $75^{\circ} \mathrm{C}$ was obtained. Weight loss after cooking was used as $\%$ cooking loss: $100 \times$ (weight loss) / initial weight.

\section{Sensory analysis}

The sensory evaluation of fish salami followed the method described by Siddaiah et al. (2001) using a panel of 5-7 experts familiar with the sensory evaluation of seafood. Three pieces of salamis were cut into pieces in two $\mathrm{cm}$ thick. For each panelist and 3 slices from the same salami sample were served. The salamis were shared to five plates, so each panelist could both examine 3 samples and served at the same time. During the panelists, five sensory criteria were evaluated as appearance, color, smell, texture and taste. The evaluators were also asked to specify the general acceptability score based on the five sensory features.

\section{Statistical analyses}

SPSS statistical package (SPSS 15.0 for Windows, SPSS Inc, Chicago, IL, USA) was used to perform the analysis. The difference of means between pairs was resolved with confidence intervals using a T-Test. The level of significance was set for $\mathrm{P}<0.05$.

\section{RESULTS AND DISCUSSION}

\section{Textural profile results}

The mean mechanical properties of Texture Profile Analysis (TPA) tests press peak values are summarized in Table 1. Commercial meat salami and produced fish salami were compared due to their mechanical properties. Hardness and chewiness, in this fish-based product, had values 49.47 (N) and $22.34(\mathrm{Nmm})$, respectively. These values were nearly two and three times lower than the taken values from meat salami $(P<0.05)$. But on the other hand, results were little bit higher than the meat salami reported by Llull et al. (2002). Similar values for textural parameters were mentioned in the papers of other researchers in meat products: hardness between 21.3 and $35.3 \mathrm{~N}$ for salami (Letelier et al., 1995) and chewiness between 11.6 and $22.8 \mathrm{~N}$ for dry-cured hams (Monin, 1998). Moreover, in a cooked meat product such as bologna sausages, hardness values ranged between 27.1 and $45.8 \mathrm{~N}$ (Jimenez, 1995). Cohesiveness is a measure of the degree of difficulty to break down the internal structure of the salami. The cohesiveness of prepared salami samples was 0.51 where the value from meat salami was 0.0 . Springiness represents the extent of recovery of salami height and sometimes referred to as "elasticity" (Sanderson, 1990). Presented data on Table 1 was 1.05 in fish salami and 0.01 in meat salami. In general, the addition of water and ice in salami preparation made the structure softer and less breakable but the potato starch and soy flour made the product substantial supported by the evidence of the data observed above. The difference of fish and meat salamis in TPA results can be seen in Table 1. As known, soybean protein has protein structure to increase and stabilize oil emulsions and the ability to increase viscosity, tissue and moisture retention and total yield in emulsified products (Kinsella, 1979) so in future work on balancing mechanical properties with potato starch and soya flour content should also be augmented in fish salami.

Table 1. Texture profile anlysis results of fish and beef salamis

\begin{tabular}{lllllll}
\hline Products & Hardness $(\mathrm{N})$ & Adhesiveness & Springiness $(\mathrm{mm})$ & Cohesviness & Chewiness (Nmm) & Resilience \\
\hline Fish salami & $49.47 \pm 1.6^{\mathrm{a}}$ & $-30.23 \pm 4.0^{\mathrm{a}}$ & $1.05 \pm 0.0^{\mathrm{a}}$ & $0.51 \pm 0.0^{\mathrm{a}}$ & $22.34 \pm 7.5^{\mathrm{a}}$ & $0.05 \pm 0.0^{\mathrm{a}}$ \\
Beef salami & $104.21 \pm 21.6^{\mathrm{b}}$ & $-0.01 \pm 0.0^{\mathrm{b}}$ & $0.01 \pm 0.0^{\mathrm{b}}$ & $0.00 \pm 0.0^{\mathrm{a}}$ & $60.5 \pm 22.0^{\mathrm{b}}$ & $0.00 \pm 0.0^{\mathrm{a}}$ \\
\hline
\end{tabular}

Different superscript letters in the same column indicate significant differences $(P<0.05) n=10$ 
The mean mechanical properties from the Kramer shear and Warner Bratzer compression tests press peak values are summarized in Table 2. The shear force values of fish salami were determined by using two mechanical tests. The shear force results were 50.80 and 50.82 , respectively. And the firmness values were $3.71 \mathrm{~N}$ (taken by Warner Bratzler from whole) and $2.70 \mathrm{~N}$ (taken from pate penetration Test). On the other hand, taken data from meat salami were $166 \mathrm{~N}$ and 178.4 $\mathrm{N}$ (Shear force), these values were three times higher than fish salami. Formulated meat texture depends on the composition and processing conditions used. In addition, these factors affect product skin formation, which is also due to salt activation and heat coagulation of myofibrils and sarcoplasmic muscle proteins (Terrell et al., 1991). In contrast, texture measurements have shown that fish salami samples do not contribute as effectively as tissue strength of chicken or red meat myofibril proteins. As already mentioned, it is known that the quality of proteins and oil affects the textural properties of processed foods (Park et al., 2001). But addition of texture modifying agents like potato starch and soy flour, the product became more substantial. These results were similar with the study of Moreira et al. (2002) who prepared emulsified sausage from tilapia fillets to determine their textural parameters. The results obtained are also consistent with the other studies showing that the addition of soy protein or starch improves textural properties by reducing product stiffness (Dawkins et al. 2001; Ho et al., 1997; Prabhu and Sebranek, 1997). Ho et al. (1997) reported that the addition of tofu powder to lean frankfurters improved product texture. In a previous study, Lee (1985) showed that when fish muscle was chopped with $\mathrm{NaCl}$ and sodium polyphosphate, a considerable reduction in compressive strength and a marked increase in shear strength occurred after the material was frozen and thawed compared to the fresh material.

Table 2. Mechanical properties of fish and beef salamis and cooking loss results

\begin{tabular}{|c|c|c|}
\hline Methods & Fish salami & Beef salami \\
\hline \multicolumn{3}{|l|}{ Kramer Test } \\
\hline Force(N) & $50.8 \pm 4.2^{a}$ & $166.0 \pm 1.8 \mathrm{~b}$ \\
\hline \multicolumn{3}{|c|}{ Warner Bratzler } \\
\hline Firmness (N) & $3.7 \pm 0.3^{a}$ & $6.76 \pm 1.9 \mathrm{~b}$ \\
\hline Force $(\mathrm{N})$ & $50.8 \pm 2.9$ a & $178.4 \pm 18.8^{b}$ \\
\hline \multicolumn{3}{|c|}{ Pate penetration (N) } \\
\hline & $2.7 \pm 0.2^{a}$ & $3.6 \pm 0.3^{b}$ \\
\hline \multicolumn{3}{|l|}{ WHC $(\%)^{a, b}$} \\
\hline & $11.1 \pm 0.1 \mathrm{a}$ & $14.0 \pm 0.2^{b}$ \\
\hline \multicolumn{3}{|c|}{ Cooking loss $(\%)^{b}$} \\
\hline & $11.0 \pm 0.1^{\mathrm{a}}$ & $8.1 \pm 0.1^{b}$ \\
\hline
\end{tabular}

\section{Cook loss and water holding capacity (WHC) results}

One of the important features of salami and other emulsified products is its ability to retain and bind moisture and other liquids in the product both before and after the process. In the present study, cooking loss describes the measurement of the amount of moisture lost during cooking. Water-holding capacity (WHC) test is used to measure how well liquids are kept in the cooked product. Cooking loss and water holding capacity of fish and meat salam sample are shown in Table 2. Due to the results $3 \%$ difference was determined. Chang and Carpenter (1997) reported that higher expressible moisture values were found with increased addition of water and lower levels of oat bran. The WHC can be observed to increase and cooking losses decrease with increased addition of soy flour (Dzudie et al., 2002). Sodium polyphosphate is known to act synergistically with $\mathrm{NaCl}$, and increases the water holding capacity of different meat preparations (Huffman et al., 1981; Moore et al., 1976; Neer and Mandigo, 1972) as well as stabilizes color, increases binding among meat particles, and improves cooking yield (Rongey and Bratzler, 1996). As shown in Table 2 cooking loss of fish salami was $11 \%$ and the expressible value was determined as $11.12 \%$. Kerr et al. (2005) suggested that the presence of texture-modifying extenders may reduce binding among the proteins rather than the water binding property of the extenders. The influence of texture-modifying agents on hardness associated with the water binding property of the agents is complicated and remains in dispute. So in the production of fish salami 1.36 $\mathrm{g} / 100 \mathrm{~g} \mathrm{NaCl}$ and $0.17 \mathrm{~g} / 100 \mathrm{~g}$ sodium phosphate was used and determined enough for a substantial product. But to equalize it with meat salami, these ratios should be increased. Pepper and Schmidt (1975) reported that a $2.0 \mathrm{~g} / 100 \mathrm{~g} \mathrm{NaCl}$ and $0.5 \mathrm{~g} / 100 \mathrm{~g}$ sodium phosphate was an optimal combination for obtaining the highest cook yield in red meat product.

\section{Color results}

Color is one of the sensory properties that can easily affect the consumer opinions. Visual appearance and color are important factors in consumer's selection of food (Francis and Clydesdale 1975; Hutchings 1999). The colors of meat salamis occurred generally in red or pink colors. By using color additives, it was possible to make salamis with traditional meat salami color. In the study of Gimeno et al. (2000) color values of traditional meat sausage were determined as follows; for $L^{*}$ value 56.14 , for $a^{*}$ value 16.85 and for $b^{*}$ value 10.63 . But in fish salami the $L^{*}$ value was determined 68.35 . $a^{*}$ and $b^{*}$ values can be observed in Table 3. Big difference can be seen in redness $\left(a^{*}\right)$ value when compared with meat salami like the stated data of Gimeno et al. (2000). Fish salami was determined to be much less red and nearly same yellow. Similar color results can be seen in the study by Koizumi and Nonaka (1980).

\section{Sensory results}

According to the results of sensorial evaluation for each attribute scores were observed higher than 8.0 points. The reported scores show the panel means values (Figure 1). An overall acceptability score of 5 was defined as the lower limit for acceptance. According to the results of overall acceptability, 
the panelist found the product in the range of "like extremely". Although the taste of the products was different from meat salami, texture effects dominated the acceptability and the comparison of the product. Lee et al. (1976) reported a good correlation between textural properties and sensory attributes of frankfurters prepared by employing various formulations and processing parameters. This was also true for similar products prepared from chicken (Prusa et al., 1982). Shehata et al. (1989) declared that $6 \%$ of added soy flour to fish protein gave the most favorable sensory scores but the soy flour content of the current study was $2.98 \%$ and this content found favorable. In a review article, Szczesniak (1963) argued that properly conducted evaluation tests should yield reliable correlations between instrumental and sensory measurements, especially, for hardness. Thus, instrumental hardness was highly correlated with sensory texture followed by over all acceptability. Acceptable textural desirability was obtained in the presence of $1.70 \%$ starch and $1.70 \%$ soy flour in the formulation and this was further improved with the addition of selected spices. But these textural properties should be strengthened if the product aimed to be just like meat salami. These kinds of emulsified products are very sensitive when it comes to consumer acceptance. Whereas other foods compete for consumer preference by, for example, innovating new products and flavors, meat is often graded just by its texture, a factor linked to its perceived quality. Texture and the appearance are the primary considerations made by a consumer in emulsified products. If the texture is too tough or too tender, or its texture has changed, perceptions of the product are normally affected.

Table 3. Color measurement result of fish and beef salamis

\begin{tabular}{lccl}
\hline Products & $\mathbf{L}^{*}$ & $\mathbf{a}^{*}$ & \multicolumn{1}{c}{$\mathbf{b}^{*}$} \\
\hline Fish Salami & $68.35 \pm 0.42^{\mathrm{a}}$ & $9.78 \pm 0.14^{\mathrm{a}}$ & $10.64 \pm 0.14^{\mathrm{a}}$ \\
Beef salami & $52.14 \pm 0.21^{\mathrm{b}}$ & $17.50 \pm 0.5^{\mathrm{b}}$ & $9.15 \pm 0.10^{\mathrm{b}}$ \\
\hline
\end{tabular}

Different superscript letters in the same column indicate significant differences $(P<0.05) n=10$

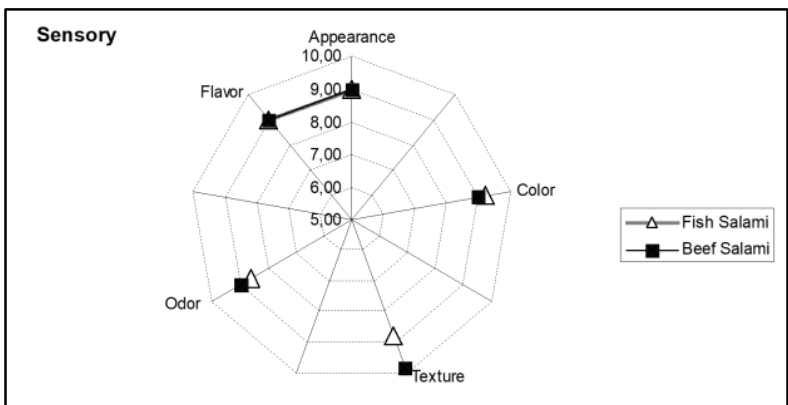

a:Score points: 9-like extremely; 8-like very much; 7-like moderately; 6-like slightly; 5-neither like nor dislike; 4-dislike slightly; 3-dislike moderately; 2-dislike very much; 1-dislike extremely

Figure 1. Sensory results of overall acceptability

\section{CONCLUSION}

There are dozens types of salamis in the markets but main differences in their types depend on the changes in their texture and flavor. Types are produced due to the character and

\section{REFERENCES}

Boles, J.A. \& Swan, J.E. (1996). Effect of post-slaughter processing and freezing on the functionality of hot-boned meat from young bull. Meat Science, 44: 11-18. doi:10.1016/S0309-1740(96)00076-9

Botta, J.R. (1991). Instrument for non-destructive texture measurement of raw Atlantic cod fillets. Journal of Food Science, 56:962-964. doi: 10.1111/j.1365-2621.1991.tb14616.x

Cardoso, C., Mendes, R. \& Nunes, M. L. (2008). Development of a healthy lowfat fish sausage containing dietary fibre. International Journal of Food Science and Technology. 43:276-283. doi:10.1111/j.1365-2621.2006.01430.x traditions of the countries in the world. Essentially most of the salamis are made from pork and meat but the finished product varies according to the kind of meat used and seasoning. But the most important factor for the consumer choice is the texture of the product. That was the reason why the current study based on the texture and the comparison. Research was containing fish salami production and comparison with the most preferred meat salami. Due to the reported results sustainable textural properties were determined for the consumers. Sensorial panel showed us that softer texture might be acceptable for fish salamis. This was the first report on fish salami produced with saithe (Polachius virens. L) in Turkey. In future studies shelf life of this product should be determined and different formulations should be denied.

\section{ACKNOWLEDGEMENTS}

This study was supported by Ege University Scientific Research Projects Coordination Unit (Project No. 2012-SÜF014). Used data are taken from the project results. Special thanks to the R\&D team of Pinar Meat Company.

Chang, H.C. \& Carpenter, J.A. (1997). Optimizing quality of frankfurters containing oat bran and added water. Journal of Food Science, 62:194197. doi: 10.1111/j.1365-2621.1997.tb04398.x

Dawkins, N.L., Gager, J., Cornillon, J.P., Kim, Y., Howard, H. \& Phelps, O. (2001). Comparative studies on the physicochemical properties and hydration behavior of oat gum and oat trim in meatbased patties. Journal of Food Science, 66:1276-1282. doi:10.1111/j.1365-2621.2001.tb15201.x 
De Deckere, E.A.M., Korver, O., Verschuren, P.M. \& Kantan, M.B. (1998) Health aspects of fish and n-3 polyunsaturated fatty acids from plant and marine origin, European Journal of Clinical Nutrition, 52:749-753. doi:10.1016/0309-1740(86)90009-4

Dzudie, T., Scher, J. \& Hardy, J. (2002). Common bean flour as an extender in beef sausages. Journal of Food Engineering, 52:143-147. doi:10.1016/S0260-8774(01)00096-6

Francis, F.J. \& Clydesdale, F.M. (1975). Food colorimetry: theory and applications. AVI Publishing. Westport:477.

Gerigk, K., Hildebrand, G., Stephan, H. \& Wegener, J. (1986). Liver sausage and the food regulations. Fleischwirtsch, 66:882.

Gimeno, O., Astiasaran, I. \& Bello, J. (2000). Calcium ascorbate as a potential partial substitute for $\mathrm{NaCl}$ in dry fermented sausages: effect on colour, texture and hygienic quality at different concentrations. Meat Science, 57:23-29. doi:10.1016/S0309-1740(00)00070-X

Ho, K.G., Wilson, L.A. \& Sebranek, J.G. (1997). Dried soy tofu powder effects on frankfurters and pork sausage patties. Journal of Food Science, 62:434-437. doi:10.1111/j.1365-2621.1997.tb04020.x

Huffman, D.L., Cross, H.R., Campbell, K.J. \& Cordray, J.C.(1981). Effect of salt and tripolyphosphate on acceptability of flaked and formed hamburger patties. Journal of Food Science, 46:34-36. doi: 10.1111/j.1365-2621.1981.tb14524.x

Hutchings, J.B. (1999). Food color and appearance. ASPEN Publishing, Gaithersburg: 613 .

Jimenez, F. Carballo, J. \&. Solas, M.T. (1995). The effect of use of freezethawed pork on the properties of Bologna sausages with two fat levels Journal of Food Science Technology, 30:335-345. doi:10.1111/j.1365-2621.1995.tb01382.x

Kao, W.T. \& Lin, K.W. (2006). Quality of reduced-fat frankfurter modified by konjac-starch mixed gels. Journal of Food Science, 71(4):326-332. doi: 10.1111/j.1750-3841.2006.00003.X

Kerr, W.L., Wang, X. \& Choi, S.G. (2005). Physical and sensory characteristics of low-fat Italian sausage prepared with hydrated oat. Journal of Food Quality, 28:62-77. doi: 10.1111/j.1745-4557.2005.00010.x

Kinsella J.E. (1979). Functional properties of soy proteins. Journal of American Oil Chemists Society, 56:242-258. doi:10.1007/BF02671468

Koizumi, C. \& Nonaka, J. (1980). Color development of fish sausage with ferrihemochrome-forming nitrogenous bases as possible substitues for nitrite. Bulletin of the Japan Society of Scientific Fisheries, 46(3):373-380

Konno, K. (2005). New developments and trends in kababoko and related research in Japan. In: J.W. Park, (Ed), Surimi and surimi seafood (pp847868), CRC Press, Taylor \& Francis.

Kris-Etherton, P.M., Krummel, D., Russell, M.E., Dreon, D., Mackey, S., Borchers, J. \& Wood, P.O. (1988). The effect of diet on plasma lipids lipoproteins and coronary heart disease. Journal of the American Dietetic Association, 88:1373-1400.

Lee, C.M. (1985). Microstructure of meat emulsions in relation to fat stabilization. Food Microstructure, 4:63-72.

Lee, C.M. Whiting, R.C. \& Jenkins, R.K. (1987). Texture and sensory evaluations of frankfurters made with different formulations and processes. Journal of Food Science, 52: 896-897. doi: 10.1111/j.1365-2621.1987.tb14237.x

Lee, C.M. \& Toledo, R.T. (1976). Factors affecting textural characteristics of cooked comminuted fish muscle. Journal of Food Science, 41:391-392. doi: 10.1111/j.1365-2621.1976.tb00627.x

Letelier, V. Kastner, C.I., Kenney, P.B., Kropf, D.H., Hunt, M.C. \& Garcla, C.M. (1995). Flaked sinew ddition to low-fat cooked salami. Journal Food Science, 60(2):245-249. doi: 10.1111/j.1365-2621.1995.tb05647.x

Llull, P. Simal, S., Benedito, J. \& Rosselló, C. (2002). Evaluation of textural properties of a meat-based product (sobrassada) using ultrasonic techniques. Journal of Food Engineering. 53(3):279-285. doi:10.1016/S0260-8774(01)00166-2

Monin, G. (1998). Recent methods for predicting quality of whole meat. Meat Science, 49(1):231-243. doi: 10.1016/S0309-1740(98)90051-1
Moore, S.L., Theno, D.M., Anderson, C.R. \& Schmidt, G.R. (1976). Effect of salt, phosphate and some nonmeat proteins in binding strength and cook yield of a beef roll. Journal of Food Science, 41:424-426. doi: 10.1111/j.1365-2621.1976.tb00633.x

Moreira, R.T., Lemos, A.L.D.S.C. \& Cristianini, M. (2002). Effect of fat content and soy isolate protein on texture of fish emulsified type sausage. 3-7 Jun 2002 Annual Meeting and Food Expo - Anaheim, California USA

Neer, K.L. \& Mandigo, R.W. (1972). Effects of salt, sodium tripolyphosphate and frozen storage time on properties of flaked, cured pork product. Journal of Food Science. 42:738-742. doi: 10.1111/j.1365-2621.1977.tb12592.x

Panpipat, W. \& Yonsawatdigul, J. (2008). Stability of potassium iodide and omega-3 fatty acids in fortified freshwater fish emulsion sausage. LWT Food Science and Technology, 41(3):483- 492. doi: 10.1016/j.Iwt.2007.03.013

Park, J., Rhee, K.S., Keton, J.T. \& Rhee, K.C. (1989). Properties of low-fat frankfurters containing monounsaturated and omega-3 poly-unsaturated oils. Journal of Food Science, 54(3):500-504. doi:10.1111/j.1365-2621.1989.tb04637.x

Pepper, F.H. \& Schmidt, G.R.(1975). Effect of Blending time, salt, phosphate, and hot-boned beef on binding strength and cook yield of beef rolls. Journal of Food Science, 40:227-230. doi: 10.1111/j.1365-2621.1975.tb02168.x

Perchonok, M.H. \& Regenstein, J.M. (1986). Stability at comminution chopping temperatures of model chicken breast muscle emulsions. Meat Science, 16:17-29

Prabhu, G.A. \& Sebranek, J.G. (1997). Quality characteristics of ham formulated with modified corn starch and kappa-carrageenan. Journal of Food Science, 62:198-202. doi: 10.1111/j.1365-2621.1997.tb04399.x

Prusa, K.J., Bowers, J.A. \& Chambers, E. (1982). Instron measurements and sensory scores for texture of poultry meat and frankfurters. Journal of Food Science, 47:653-654. doi: 10.1111/j.1365-2621.1982.tb10142

Ravishankar, C.N., Setty, T.M.R. \& Shetty, T. S. (1992). Method for the preparation of sausages of acceptable quality from Indian oil sardine (Sardinella longiceps) and their shelf-life at different storage temperatures. Food Control, 3(3):144-148. doi:10.1016/0956-7135(92)90098-U

Rongey, E.H. \& Bratzler, L.J. (1966). The effect of various binders and meats on the palatability and processing characteristics of Bologna. Food Technology, 20: 1228-1231.

Sanderson, G.R. (1990). Gellan gum. In: P. Harris, (Ed), Food gels, (pp 201 232) New York: Elsevier.

Sawyer, C.A. Biglari, S.D. \& Thompson, S.S. (1984). Internal end temperature and survival of bacteria on meats with and without a polyvinyl chloride wrap during microwave cooking. Journal of Food Science, 49:972-974. doi: 10.1111/j.1365-2621.1984.tb13260.x

Schubring, R. (2003). Colour measurement for the determination of the freshness of fish. In: J.B. Luten, J. Oehlenschlager and G. Olafsdottir, (Ed), Quality of fish from catch to consumer: Labelling, monitoring and traceability (pp 251-263) The Netherlands: Wageningen Academic Publishers.

Schubring, R. (2002). Texture measurement on gutted cod during storage in ice using a hand-held instrument. Inf Fischwirtsch Fischereiforsch. 49:2527.

Shehata, N.A., Ibrahim A.A. \& Ghali, N.N. (1989). Effect of supplementing wheat flour with fish protein concentrate-chemical and organoleptic evaluation. Die Nahrung, 6:497-501.

Siddaiah, D., Reddy, G.V.S., Raju, C.V. \& Chandrasekhar, T.C. (2001). Changes in lipids, proteins and kamaboko forming ability of silver carp (Hypophthalmichthys molitrix) mince during frozen storage. Food Research International, 34:47-53. doi: 10.1016/S0963-9969(00)00127-7

Sikorski, Z. \& Sun Pan, B. (1991). Preservation of seafood quality. In F. Shahidi J.R. Botta, (Ed.),Seafoods: Chemistry, processing technology and quality(pp 168-195). UK: Blackie Academic and Professional.

Smewing, J. (1996). Texture Analysis. Meat International. 6(7): 37-38. 
Su, Y.K., Bowers J.A. \& Zayas, J.F. (2000). Physical characteristics and microstructure of reduced-fat frankfurters as affected by salt and emulsified fats stabilized with nonmeat proteins. Journal of Food Science, 65(1):128-132. doi: 10.1111/j.1365-2621.2000.tb15966.x

Szczesniak, A.S. (1963). Objective measurements of food texture. Journal of Food Science, 28:410-420. doi: 10.1111/j.1365-2621.1963.tb00219

Terrell, R.N., Ming, C.G., Jacobs, J.A., Smith, G.C. \& Carpenter Z.L. (1981) Effect of chloride salts, acid phosphate and electrical stimulation on $\mathrm{pH}$ and moisture loss from beef clod muscles. Journal of Animal Science, 53:658-659.

Trautwein, E.A. (2001). N-3 fatty acids-physiological and technical aspects for their use in food. European Journal of Lipid Science Technology, 103:45-55.

doi: 10.1002/1438-9312(200101)103:1<45::AID-EJLT45>3.0.CO;2-9

Yoon, K.S., Lee, C.M. \& Hufnagel, L.A. (1991). Effect of washing on the texture and microstructere of frozen fish mince. Journal of Food Science, 56: 294298. doi: 10.1111/j.1365-2621.1991.tb05265.x 